\title{
Linkage between Entrepreneurial Competency and Social Entrepreneurship: Evidences from SMEs in Kerala
}

\author{
Minimol M. C. ${ }^{1}$ \\ 1 Rajagiri Centre for Business Studies, Rajagiri College of Social Sciences(Autonomous), Rajagiri Valley, \\ Kakkanad, Kochi, Kerala, India \\ Correspondence: Minimol M. C., Rajagiri Centre for Business Studies, Rajagiri College of Social Sciences \\ (Autonomous), Rajagiri Valley, Kakkanad, Kochi, Kerala, India. Tel: 98-4632-9021. E-mail: \\ minimol@rajagiri.edu
}

Received: July 20, 2017

Accepted: August 23, $2017 \quad$ Online Published: September 28, 2017

doi:10.5539/ass.v13n10p31

URL: https://doi.org/10.5539/ass.v13n10p31

\begin{abstract}
Social entrepreneurs initiate social innovation and transformation in different fields such as education, health, environment, finance and even business management. They are keen in pursuing poverty alleviation goals while undertaking various activities with entrepreneurial zeal, business methods and exhibit the courage and commitment to renovate and transform traditional practices. The present study was conducted with a view to find out the extent to which entrepreneurial competency supports the development of social entrepreneurship and to develop a model explaining the linkage between entrepreneurial competency and social entrepreneurship. The methodology adopted in the study was a combination of exploratory, descriptive and explanatory research designs. Findings of present study pinpoint the statistically significant direct positive relationship between the two variables. Policy makers, while designing various training and development programs for micro entrepreneurs, can focus on various entrepreneurial competency factors, which can potentially contribute to the characteristic of social entrepreneurship among them.
\end{abstract}

Keywords: Social entrepreneurship, entrepreneurial competency, micro entrepreneurs, social innovation

\section{Introduction}

Over the past three decades social enterprize has grown drastically in many regions of the world. Broadly explained as the predominant usage of nongovernmental and market-based approaches to address booming social issues, social enterprize provides a source of revenue for many types of organizations and activities having a social-focus. This revenue often contributes to the long-term sustainability and self-sufficiency of organizations involved in various charitable activities (Kerlin, 2006).

Social entrepreneur may innovate or renovate opportunities. (Alvarez and Barney, 2007) and establish ventures to generate profit, produce wealth or to establish a balance between social and economic requirements. The socially responsible ventures may be created by individual entrepreneurs as well as companies (Prahlad, 2006). Because profit and nonprofit-making social ventures develop the organisations and infrastructure essential for development, they can be treated as the engine of societal development. Largely, social enterprizes are businesses, fabricated to make profit. The profit, which is reinvested to meet the social aims of the business is the real distinguishing factor.

The present study was conducted with a view to analyse the extent to which entrepreneurial competency contributes to the development of social entrepreneurship among micro entrepreneurs in Kerala and to build a theoretical model that can possibly explain the intricacies involved in the linkage between entrepreneurial competency and social entrepreneurship. The study was structured in broad headings such as Introduction, review of literature, objectives, rationale for the study, methodology, analysis, conclusion, managerial implications, scope for future research and references.

\subsection{Review of Literature}

The review of literature is arranged under two different heads such as entrepreneurial competencies, and social entrepreneurship. 


\subsubsection{Entrepreneurial Competency}

Mitchelmore and Rowley (2010) had done a review of literature regarding research on entrepreneurial competencies to present a detailed account of studies in the field of entrepreneurial competencies by various authors (Boyatzis, 1982; Brophy \& Kiely, 2002; Parry, 1998; Thompson, 1997; Woodruffe, 1992) and, develop a framework for further research, and practice in the field of entrepreneurial competencies. After a detailed examination of available literature in the field, they advocated that the concept entrepreneurial competency has been used in different areas and agencies as part of their campaign for economic development and business accomplishment. The spirit of entrepreneurial competencies, its valuation and its association to entrepreneurial performance and business accomplishment is in need of further meticulous research and development. Many researchers (Iman, 2005; Man et al., 2002; Adam \& Shell, 1993; Barlett \& Ghoshal, 1997; Baum, 1994; Bird, 1995; Chandler \& Jansen, 1992; Durkan et al., 1993; Gasse, 1997; Hunt, 1998; Lau et al., 1999; McClelland, 1987; Milton, 1989; Snell \& Lau, 1994) have taken efforts to study the components of entrepreneurial competency and its association with entrepreneurial performance. Competency is all about the long term aspect of a firm performance, an industry or a country performance in relation to its competitors says Ramasamy (1995). It is also a multi-faceted concept, including not only performance, but also potential and the prospect of ensuring performance. The competency approach envisages a technique for studying individual traits heading to the achievement of job goal for organisational success. It was widely employed to study managerial performance in organisations since the work of Boyatzis (1982) and popularly used in the field of entrepreneurial performance. By adopting numerous qualitative techniques, many studies have been carried out to identify entrepreneurial competency (Adam \& Chell, 1993; Bird, 1995).

In the current study, entrepreneurial competences are taken as individual traits consisting of both attitude and behaviour that facilitate entrepreneurs to attain and sustain business success. In the present study entrepreneurial competency include entrepreneur's motives, traits, self-image, attitude, behaviour, skill sets and knowledge (Boyatzis,1982; Brophy \& Kiely, 2002), measured with the help of 47 variables, which were grouped into four different factors.

\subsubsection{Social Entrepreneurship}

A social entrepreneur deliberates productively and contributes a new result that radically interrupts with the existing one. They are instigated to change the hostile balance. They exhibit bravery all the way through the process of innovation or renovation, accepting the responsibility of risk and gazing at failure directly or repeatedly, always look for change; retort to it and utilize it as a prospect. They possess exceptional traits such as; vigilance, stimulus, creativeness, direct action, bravery and strength. Wilkund (1998), stresses that there's a durable relationship between entrepreneurial competency and apparent functioning of enterprizes. Thompson et al., (2002) acknowledges that social entrepreneurs are ruthless in character, goal driven, creative, and enigmatic and result oriented, which drives them to goal accomplishment. Selflessness and efficacy are some of the behavioral competencies that are positively related to apparent performance of social entrepreneurs. It is also important that, whether they are functioning in local or international level, social entrepreneurs are result oriented, and have an obligation to act as a catalyst for innovation that reshapes the entire world and assist human society at large. Social entrepreneur, thus, develop as a sporadic individual with numerous traits and characteristics including the ability to analyze, visualise, converse, empathize, stimulate, promotes, intercede, facilitate and empower a wide range of frantic individuals and organizations. According to Zampetakis (2008), social entrepreneurs are track breakers with influential ideas that merge visionary and real world problem-solving capability, having robust ethical make up and are really dominated by their vision for transformation. Logma (2004) has come out with five characteristics that social entrepreneurs possess:

1. Embracing a mission to create and uphold social value;

2. Comprehending and persistently tracking searching new ways to serve that mission;

3. Participating in a process of incessant innovation, revision and scholarship;

4. Acting daringly without controlled by current means in hand; and

5. Demonstrating a sharp sense of responsibility to the communities served and to the results generated.

Hence, the faster an individual fulfils these criteria, the better that individual falls in the prototype of a social entrepreneur. But he also accepts that in several manners, the literature regarding social entrepreneurship explains a set of traits and competencies that are outstanding. These traits should be inspired and those who have the competencies needs to be rewarded for their temperament for this sort of work.

Thompson et al., (2000) pointed out that a social entrepreneur's competencies are manifested in his/her ability to pool resources, stimulate, defend, associate, corroborate and persuade the different stakeholders and reassure 
them of the a value addition on account of attempting something new. The successful social entrepreneur will not attach to one version of his/her 'truth'. Truth is relative and can be expressed in several ways to different stakeholders. Mostly when the social entrepreneur already has access to means that would support his/ her description of choices, space of opportunity may more readily be opened. Zampetakis (2008) affirm that the position of a social entrepreneur is not different, from that of a change agent. Accordingly, a social entrepreneur is not necessarily apprehensive with the management of change. There is apparent difference between the two designations. The change agent would primarily act as a catalyst of change, whereas the manager of change would be involved in change processes themselves.

Cannon (2000) categorize three different class of people who become social entrepreneurs. The first type are individuals who made enough money elsewhere and are hence, interested in giving some of it back to achieve social goals. The second type is 'recovering social workers' who are dissatisfied in the existing social support system and waiting for a more efficient approach. The third class comprises of people who have gone to business schools with social enterprize in mind. According to Zampetakis (2008), social entrepreneurs merge street pragmatism with professional skill sets, prophetic acumens with pragmatism, an ethical strand with tactical direction. They see opportunities where others only spot vacant buildings, unemployable folks and undervalued resources. Revolutionary thinking distinguishes social entrepreneurs from other people. They make markets work for society and people, and gain strength from a wide chain of alliances. In specialized literature, a number of distinctive definitions describing social entrepreneur can be located. To conclude, except a few discrepancies, all researchers covered almost same issue: social entrepreneurs are people with a social orientation as against a profit-making objective. Their main purpose is to create social value, to arrive at innovative solutions to address social problems or market failure; the characteristic features, skill sets and strengths of a social entrepreneur have also been listed (Miller, Wesley \& Williams, 2012). Other authors have summarized the different definitions of 'social entrepreneur' published in specialized literature (Mair \& Noboa, 2003; Zahra et al., 2008; Bacq \& Janssen, 2011; Abu Saifan, 2012). More extensive research has been carried out by Francois Brouard and Sophie Larivet, They have summarized 33 definitions of social entrepreneur as found in various authors' works published from 1991 up to 2008. After summarizing they deduced that "social entrepreneurs are people, with entrepreneurial quest and personality, they will play the role change agents and leaders to handle and resolve social problems by taking advantage of new opportunities and finding innovative solutions, and are also concerned with producing social value than creating financial value" (Brouard \& Larivet, 2010). It is imperative to notice the aspect, that a social entrepreneur should have well-developed social and entrepreneurial competence is not mentioned in many of the published definitions of 'social entrepreneur', except for some authors who consider that entrepreneurial spirit is very important for a social entrepreneur (CCSE, 2001), or that solution of social problems will make him/her adopt entrepreneurial behaviour (Janssen, 2011); that social entrepreneurs act entrepreneurially through a combination of characteristics (Abu, Saifan, 2012). Veronika Bikse et al. (2015), in their study the social entrepreneur as a promoter of social advancement explained the concept of social entrepreneur, and tried to identify Latvia's social entrepreneurs in the context of entrepreneurship based on a review of related literature, a survey of social entrepreneurs and expert interviews. On the basis of an analysis of the existing literature, a theoretical outline of entrepreneurial competencies is created which forms the basis for the practical solution of the research problem. Combination of survey and interview methods was used for learning about a social entrepreneur's personal traits and skill sets, main motivations and opportunities to create social enterprises and to develop entrepreneurship, as well as to learn about the potential gains, risks and sustainability of development social enterprises. The results of the research pointed out that, in order to encourage social entrepreneurship, more attention should be paid to the training of social entrepreneurs in the education system, as well as the development and implementation of the conceptual action plan of the government, and also the provision of several support instruments.

There exists gaps in the literature, in terms of the dimensions (strategic management, financial management, personnel management and operational management) covered, the nature (combination of quantitative and qualitative) of the study, the context (small and micro entrepreneurs in Kerala) in which the study was undertaken, and also in terms of purpose of the study. Most of the existing studies on the topic concentrate either on entrepreneurial competency or on social entrepreneurship individually. Literature review reveals, lack of previous researches in India to establish a link between entrepreneurial competency and social entrepreneurship empirically. Almost all the studies conducted on the topic are conceptual in nature. None of the previous studies, in the area attempted to suggest a model establishing the association between entrepreneurial competency and social entrepreneurship. Many researchers have taken efforts to study the components of entrepreneurial competency in general, but no specific attempt was made to understand the dimensions of entrepreneurial competency in the framework of small and micro entrepreneurs in Kerala. 


\subsection{Rationale for the Study}

Existing literature presumed that entrepreneurial competencies significantly contributes to social entrepreneurship. But no one empirically proved the theory in Kerala. This study aims to address this gap. Hence, the present study made an attempt to cluster the variables contributing to entrepreneurial competency, into a few factors (strategic management, financial management, personnel management and operational management) and to investigate whether or not entrepreneurial competency contribute to social entrepreneurship. The study also tried to develop a conceptual model explaining the linkages between entrepreneurial competency and social entrepreneurship.

\subsection{Objectives of the Study}

Based on the gaps identified in the existing literature, two specific objectives were formulated for the study. Accordingly, the study is intended to identify the entrepreneurial competency dimensions, in the context of small and micro entrepreneurs in Kerala, and to formulate a theoretical model explaining the linkage between entrepreneurial competency and social entrepreneurship

\section{Method}

The dominant methodology used in the study was explanatory as the study examined the linkages between entrepreneurial competencies, and social entrepreneurship among micro entrepreneurs. The type of investigation carried out in the study was causal. The research strategy followed was field study, by administering a structured interview schedule. From the perspective of time horizon, a cross sectional survey was designed for the study. The primary research was quantitative in nature with qualitative methods facilitating the quantitative research. The qualitative approach involved face to face interviews with micro entrepreneurs. Survey method was used in quantitative research for collecting data from sample respondents, so data source is the micro entrepreneurs in Kerala.

Population for the study was taken as the entire micro entrepreneurs in Kerala. Sample frame is the list of micro entrepreneurs collected from the concerned District Industries Centres. The sample respondents were selected by using multi-stage, simple random sampling technique. In the first stage, five districts [Alappuzha, Kollam, Thiruvananthapuram, Ernakulam and Kottayam] were selected from the entire state of Kerala by considering the number of SMEs functioning there. In the second phase, 30 SMEs were chosen from each district, by giving weightage to the factors such as year of formation (high weightage to those started earlier), number of employees (more weightage to those having more employees), sales turnover (more weightage to those having higher turnover) etc. 300 micro entrepreneurs were selected, across the districts to constitute the sample in the third phase. Thus, the sample size came to 300 , made up of 50,61 and 56,72 and 61 respondents from the five sample districts.

Primary data were collected by employing a structured interview schedule on the selected fraction of the population. Exploratory factor analysis to define the underlying structure among variables was carried out and PLS analysis was done to study the linkage among the variables.

In this study, entrepreneurial competency is perceived as a formative construct, and social entrepreneurship as a reflective construct. To identify the factors that make up entrepreneurial competency and to reduce the indicators that form the dimensions, Exploratory Factor Analysis was carried out using SPSS 17.0 statistical package. Barlett's Test of Sphericity and Keyser Meyer Olkin Measure of Sampling Adequacy were used to determine the sufficiency of correlations in the data set for factor analysis.

The validity of the scales, both convergent and discriminant, and the reliability of the scale items were checked on WarpPLS 5.0 software. Entrepreneurial competency being a formative construct, the indicator weights and variance inflation factors (VIF) of the formative indicators were also checked to see if the values satisfied the acceptance criteria. Sample profile is given in Table 1.

Table 1. Sample Profile

\begin{tabular}{ccc}
\hline Districts & Number of SMEs & Micro Entrepreneurs \\
\hline Alappuzha & 30 & 50 \\
Kollam & 30 & 61 \\
Thiruvananthapuram & 30 & 56 \\
Ernakulam & 30 & 72 \\
Kottayam & 30 & 61 \\
Total & 150 & 300 \\
\hline
\end{tabular}


Source: Prepared by the author

The present study is intended to identify the entrepreneurial competency dimensions, in the context of small and micro entrepreneurs in Kerala, and to build a theoretical model explaining the linkage between entrepreneurial competency and social entrepreneurship. So the variables used in the study are entrepreneurial competency (independent variable), which is factored into four different dimensions, such as, strategic management, financial management, personnel management and operational management, with the help of exploratory factor analysis and social entrepreneurship (dependent variable). The variables are presented in Table 2.

Table 2. Variables used in the Study

\begin{tabular}{lcc}
\multicolumn{1}{c}{ Independent variable } & Dependent Variable \\
\hline Entrepreneurial Competency & Social Entrepreneurship \\
- $\quad$ Strategic management & \\
- $\quad$ Financial management & \\
- $\quad$ Personnel management & \\
\hline
\end{tabular}

Source: Prepared by the Author

For the current study entrepreneurial competency is defined as a construct made up of four different type of competencies such as strategic management, financial management, personnel management and operational management competencies. Social entrepreneurship is taken as a construct made up of 19 variables. The detailed analysis results are presented below.

\section{Results}

\subsection{Reliability and Validity of the Constructs}

To ensure that the instruments developed to measure entrepreneurial competency and social entrepreneurship were indeed measuring the constructs, the goodness of measures was assessed by testing the reliability and validity of the instruments. Validation tests such as convergent and discriminant validity were conducted before the PLS analysis was done.

\subsubsection{Convergent Validity}

In the study, the factor loadings associated with the latent variables ranged between 0.520 and 0.936 as shown in Table 3 and hence it was reasonable to assume that the measurement model for entrepreneurial competency has acceptable convergent validity. The loadings for each latent variable (shown in parentheses) were all high while cross loadings were low. The $\mathrm{P}$ values associated with the loadings were all lower than 0.001 .

Table 3. Combined Loadings and Cross Loadings

\begin{tabular}{cccccc}
\hline & \multicolumn{5}{c}{ Entrepreneurial Competency } \\
\cline { 2 - 6 } & $\begin{array}{c}\text { Strategic } \\
\text { Management }\end{array}$ & $\begin{array}{c}\text { Financial } \\
\text { Management }\end{array}$ & $\begin{array}{c}\text { Personnel } \\
\text { Management }\end{array}$ & $\begin{array}{c}\text { Operational } \\
\text { Management }\end{array}$ & P value \\
\hline EC31TOT & $(-0.85)$ & 0.51 & -0.63 & 0.59 & $<0.001$ \\
EC36TOT & $(-0.62)$ & -0.05 & 1.01 & -0.09 & $<0.001$ \\
EC1TOT & $(-0.89)$ & -0.24 & -0.59 & 0.02 & $<0.001$ \\
EC10TOT & $(-0.84)$ & 0.21 & -0.05 & -0.29 & $<0.001$ \\
EC13TOT & $(-0.69)$ & 0.40 & -0.53 & 0.57 & $<0.001$ \\
EC8TOT & $(-0.94)$ & -0.73 & -0.06 & 0.07 & $<0.001$ \\
EC2TOT & $(-0.89)$ & -0.47 & -0.37 & -0.00 & $<0.001$ \\
EC3TOT & $(-0.8)$ & -0.44 & -0.19 & 0.11 & $<0.001$ \\
EC9TOT & $(-0.71)$ & 1.22 & 0.18 & -0.29 & $<0.001$ \\
EC29TOT & $(-0.79)$ & 0.39 & -0.10 & 0.57 & $<0.001$ \\
EC4TOT & $(-0.75)$ & 1.48 & 1.13 & -0.34 & $<0.001$ \\
EC12TOT & $(-0.93)$ & -0.73 & -0.06 & 0.07 & $<0.001$ \\
EC43TOT & -0.67 & $(-0.76)$ & -0.25 & -0.38 & $<0.001$
\end{tabular}




\begin{tabular}{|c|c|c|c|c|c|}
\hline EC40TOT & -1.16 & $(-0.69)$ & -0.96 & -0.06 & $<0.001$ \\
\hline EC11TOT & -0.68 & $(-0.75)$ & -0.89 & -0.12 & $<0.001$ \\
\hline EC35TOT & 0.81 & $(-0.85)$ & 1.87 & 0.22 & $<0.001$ \\
\hline EC42TOT & 0.08 & $(-0.64)$ & 0.69 & -0.14 & $<0.001$ \\
\hline EC41TOT & 0.97 & $(-0.77)$ & -0.17 & 0.28 & $<0.001$ \\
\hline EC15TOT & -0.46 & $(-0.52)$ & 1.23 & -0.41 & $<0.001$ \\
\hline EC7TOT & -0.19 & $(-0.76)$ & -0.021 & 0.18 & $<0.001$ \\
\hline EC44TOT & 1.47 & $(-0.77)$ & -0.09 & 0.38 & $<0.001$ \\
\hline EC34TOT & 0.03 & -0.41 & $(-0.94)$ & 0.09 & $<0.001$ \\
\hline EC39TOT & 0.98 & 0.78 & $(-0.89)$ & 0.32 & $<0.001$ \\
\hline EC22TOT & -0.65 & -0.52 & $(-0.84)$ & 0.22 & $<0.001$ \\
\hline EC24TOT & -0.26 & 0.12 & $(-0.90)$ & -0.18 & $<0.001$ \\
\hline EC14TOT & -0.45 & 0.23 & $(-0.93)$ & -0.24 & $<0.001$ \\
\hline EC18TOT & 0.35 & -0.09 & $(-0.89)$ & -0.12 & $<0.001$ \\
\hline EC27TOT & 1.19 & 0.91 & $(-0.693)$ & 0.256 & $<0.001$ \\
\hline EC19TOT & 0.12 & 0.45 & 0.36 & $(-0.90)$ & $<0.001$ \\
\hline EC21TOT & -0.11 & 0.35 & 0.64 & $(-0.89)$ & $<0.001$ \\
\hline EC20TOT & 0.92 & -0.10 & 0.29 & $(-0.64)$ & $<0.001$ \\
\hline EC23TOT & -0.84 & 0.25 & 0.36 & $(-0.84)$ & $<0.001$ \\
\hline EC17TOT & 0.25 & -0.67 & -0.82 & $(-0.90)$ & $<0.001$ \\
\hline EC47TOT & 0.92 & -0.42 & -1.04 & $(-0.86)$ & $<0.001$ \\
\hline
\end{tabular}

Source: Factor Analysis

\subsubsection{Discriminant Validity}

As seen in Table 4, the average variance extracted for each variable (shown in parentheses) was higher than any other values, above or below it or to its left or right. Thus discriminant validity of the measurement model was established.

Table 4. Latent Variable Correlations

\begin{tabular}{cccccc}
\hline & \multicolumn{2}{c}{ Entrepreneurial Competency } & Social \\
\cline { 2 - 5 } & $\begin{array}{c}\text { Strategic } \\
\text { Management }\end{array}$ & $\begin{array}{c}\text { Financial } \\
\text { management }\end{array}$ & $\begin{array}{c}\text { Personnel } \\
\text { Management }\end{array}$ & $\begin{array}{c}\text { Operational } \\
\text { Management }\end{array}$ & Entrepreneurship \\
\hline ECF1 & $(0.73)$ & 0.57 & 0.68 & 0.03 & - \\
ECF2 & 0.67 & $(0.68)$ & 0.44 & 0.35 & - \\
ECF3 & 0.68 & 0.44 & $(0.79)$ & -0.25 & 0.80 \\
ECF4 & 0.03 & 0.35 & -0.25 & $(0.81)$ & 0.69 \\
& - & - & - & - & $(0.69)$ \\
\hline
\end{tabular}

Source: PLS Analysis

\subsubsection{Reliability - Entrepreneurial Competency Scale}

Table 5. Latent Variable Coefficients

\begin{tabular}{|c|c|c|c|c|c|}
\hline & \multicolumn{4}{|c|}{ Entrepreneurial Competency } & \multirow{2}{*}{$\begin{array}{c}\text { Social } \\
\text { Entrepreneurship }\end{array}$} \\
\hline & $\begin{array}{c}\text { Strategic } \\
\text { Management }\end{array}$ & $\begin{array}{c}\text { Financial } \\
\text { Management }\end{array}$ & $\begin{array}{c}\text { Personnel } \\
\text { Management }\end{array}$ & $\begin{array}{c}\text { Operational } \\
\text { Management }\end{array}$ & \\
\hline Composite Reliability & 0.92 & 0.88 & 0.92 & 0.89 & 0.76 \\
\hline Cronbach's Alpha & 0.92 & 0.84 & 0.89 & 0.803 & 0.72 \\
\hline $\begin{array}{c}\text { Average Variance Extracted } \\
\text { (AVE) }\end{array}$ & 0.74 & 0.86 & 0.63 & 0.66 & 0.65 \\
\hline
\end{tabular}

Source: PLS Analysis 
A measurement instrument has good reliability if the question statements associated with each latent variable are understood in the same way by different respondents. For a measurement instrument to have good reliability, both the composite reliability and Cronbach's alpha coefficients should be equal to or greater than 0.7 (Fornell and Larcker, 1981; Nunnally and Bernstein, 1994). As all the indicators were reflective latent variable indicators, the criteria apply. According to Field (2005), values between 0.7 and 0.8 of Cronbach's $\alpha$ are acceptable values of consistency. As seen in Table 5 the composite reliability coefficients ranged from 0.76 to 0.92 and the Cronbach's alpha coefficient between 0.72 and 0.92 , both well above the 0.7 threshold. It was therefore concluded that the measurement model has acceptable reliability.

\subsection{Validation of the Constructs}

Entrepreneurial Competency was conceptualized in the study as a second order formative construct on theoretical grounds. The dimensions of entrepreneurial competency with the indicators based on factor analysis is shown in Figure 1.

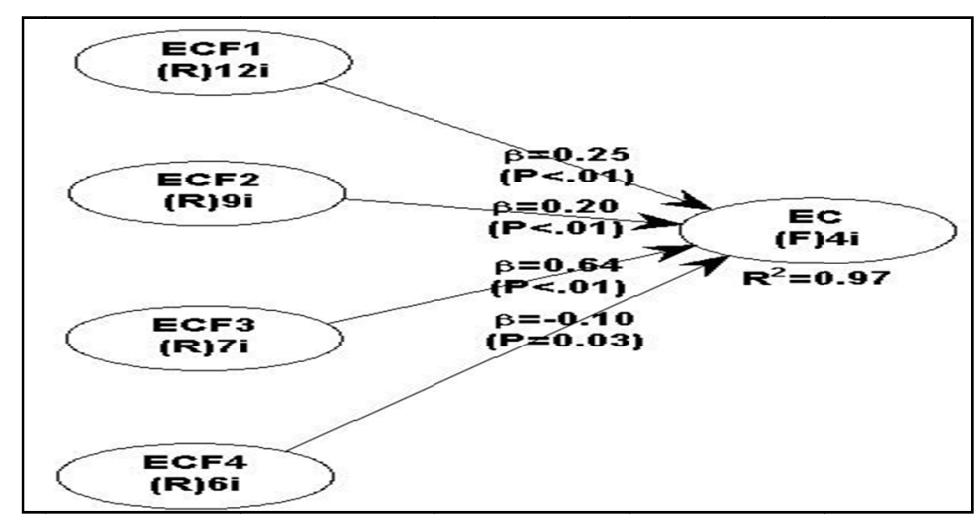

Figure 1. Entrepreneurial Competency Dimensions

Source: PLS Analysis

A Principal Component Analysis of the 47 indicators of entrepreneurial competency was performed using SPSS 17.0 statistical package to reduce the larger set of variables into a smaller, conceptually more coherent set of variables, by identifying redundancy among the variables. The Kaiser-Meyer-Olkin (KMO) measure of sampling adequacy was 0.873 , a level described as 'marvelous' by Kaiser (1974). The Bartlett's Test of Sphericity was significant $(p<0.001)$ and the test value was high at 25300.37 , leading to the conclusion that there were correlations in the data set that are appropriate for factor analysis.

Table 6. Reclassified Factor Loadings with Indicators

\begin{tabular}{|c|c|c|c|c|}
\hline \multirow[b]{2}{*}{ Indicators } & \multicolumn{4}{|c|}{$\begin{array}{l}\text { Reclassified Indicators with } \\
\text { Component Loadings }\end{array}$} \\
\hline & 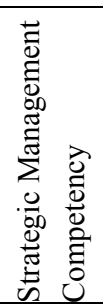 & 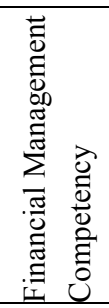 & 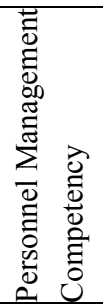 & 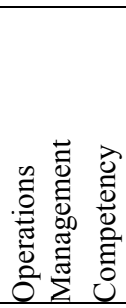 \\
\hline Ensure that activities are directed towards achieving business goals & 0.89 & & & \\
\hline Predict market movements/fluctuations correctly & 0.88 & & & \\
\hline Try out competitor's products & 0.86 & & & \\
\hline Look at solving old problems in new ways & 0.86 & & & \\
\hline Have a clear picture about the objectives of our business & 0.85 & & & \\
\hline Clearly know what to do to achieve business objectives & 0.85 & & & \\
\hline Try to bring up new ideas in the business & 0.83 & & & \\
\hline Always ready to grab a market opportunity & 0.82 & & & \\
\hline Sure about the best way to achieve the objectives & 0.77 & & & \\
\hline
\end{tabular}




\begin{tabular}{|c|c|c|c|c|}
\hline Regularly take feedback from customers & 0.75 & & & \\
\hline Continuously monitor what competitors/ peers are doing & 0.71 & & & \\
\hline Decided on what to do for the next 3-5 years in the business & 0.66 & & & \\
\hline Can predict next year's budget accurately & & 0.94 & & \\
\hline Always on the lookout for new schemes from banks, LAs etc. & & 0.92 & & \\
\hline Always do cost - benefit analysis for activities & & 0.92 & & \\
\hline Know about the return and cost of capital & & 0.91 & & \\
\hline Maintain a network of personal contacts for financial consultation & & 0.90 & & \\
\hline Have incentive system to reward above-norm performance & & 0.76 & & \\
\hline Have continuous records of cash flow analysis & & 0.71 & & \\
\hline Can plan financial needs for production according to market changes & & 0.71 & & \\
\hline Modify activities to better suit future objectives & & 0.66 & & \\
\hline Create a positive climate and culture in the business & & & 0.87 & \\
\hline Use personal contacts, influences, and relations to increase business & & & 0.87 & \\
\hline $\begin{array}{l}\text { Ensure that right people are assigned the right duties and } \\
\text { responsibilities }\end{array}$ & & & 0.86 & \\
\hline Have links with experts/advisors for help & & & 0.85 & \\
\hline Have small sub-groups assigned specific roles and activities & & & 0.80 & \\
\hline Motivate colleagues to achieve targets and goals & & & 0.71 & \\
\hline Participate regularly in meetings to discuss future actions & & & 0.69 & \\
\hline Have specific plans decided for the next one or two years & & & & 0.84 \\
\hline Always ensure sufficient supply of resources in business & & & & 0.80 \\
\hline Very keen to ensure that the business runs smoothly & & & & 0.79 \\
\hline Try to minimize cost, effort and time by analysis & & & & 0.78 \\
\hline Evaluate alternatives before selecting an action & & & & 0.74 \\
\hline Use technology to improve efficiency in production & & & & 0.68 \\
\hline
\end{tabular}

Extraction Method: Principal Component Analysis. Rotation Method: Varimax with Kaiser Normalization.

a. Rotation converged in 12 iterations. Source: Compiled from Factor Analysis Results

There are four factors that are extracted through principal component analysis. Factor one accounts for 26.492 per cent of variance of the dependant variable (Entrepreneurial Competency), is named as strategic management competency. Factor two accounts for $23.879 \%$, and is taken as financial management competency, factor three accounts for $16.851 \%$, and is considered as personnel management competency, and factor four, which accounts for $9.403 \%$ of variance in the dependant variable is taken as operations management competency. In total, the four factors extracted account for a cumulative $76.625 \%$ of the variance in the dependant variable.

\subsection{Research Model Analysis}

For the analysis of the research model, Partial Least Squares (PLS) based Structural Equation Modeling was carried out using Warp PLS 5.0 software.

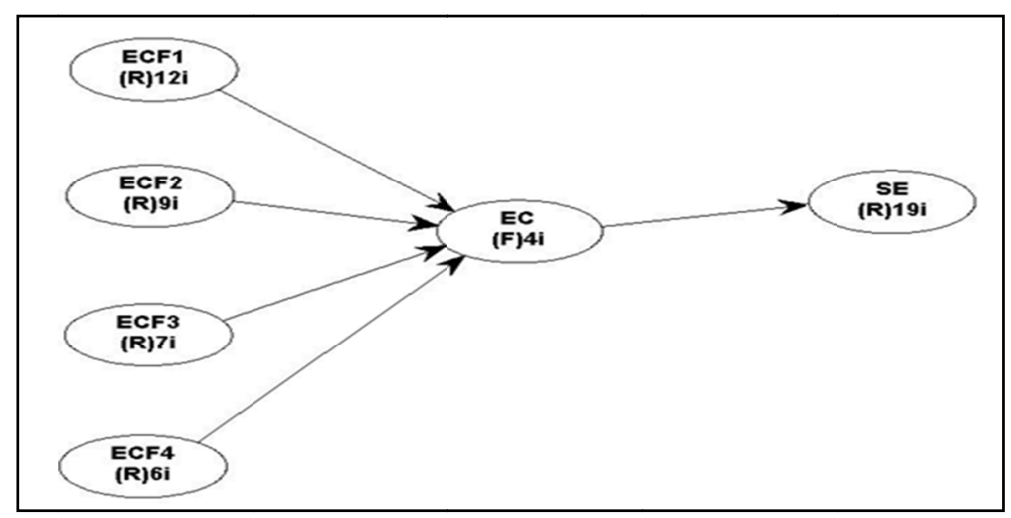

Figure 2. Research Model

Source: PLS Analysis 
The Figure 2 shows the research model with the relationship between the latent variables and also the indicators used to measure the variables. The general results of the SEM analysis are as shown in Table 7. All the criteria for model fit were, as shown in table, satisfied by the model.

Table 7. Model Fit Indices and $\mathrm{P}$ values

\begin{tabular}{l}
\hline $\mathrm{APC}=0.39, \mathrm{P}<0.001$ \\
\hline $\mathrm{ARS}=0.73, \mathrm{P}<0.001$ \\
\hline $\mathrm{AVIF}=4.02$, Good if $<5$ \\
\hline Source: PLS Analysis
\end{tabular}

\subsubsection{Latent Variable Coefficients of Measures}

In Table 8, R-squared and Q-squared coefficients are provided latent variables; and reflect the percentage of explained variance and predictive validity associated with each of those latent variables, respectively. Composite reliability and Cronbach's alpha coefficients are provided for all latent variables. Average variances extracted (AVE) and full collinearity variance inflation factors (VIFs) are also provided for all latent variables; and are used in the assessment of discriminant validity and overall collinearity, respectively. All the values of measures satisfy the acceptance criteria.

Table 8. Latent Variable Coefficients

\begin{tabular}{ccccccc}
\hline & SE & EC & ECF1 & ECF2 & ECF3 & ECF4 \\
\hline R - Squared & 0.59 & 0.97 & & & & \\
Adj. R - Squared & 0.59 & 0.97 & & & & \\
Composite Reliab. & 0.76 & 0.69 & 0.92 & 0.88 & 0.92 & 0.89 \\
Cronbach's Alpha & 0.72 & 0.80 & 0.91 & 0.85 & 0.89 & 0.80 \\
AVE & 0.65 & 0.69 & 0.74 & 0.86 & 0.63 & 0.66 \\
Q - Squared & 0.56 & 0.96 & & & & \\
\hline
\end{tabular}

Source: PLS Analysis

\subsubsection{Path Coefficients and P values}

The estimated model with path coefficients and corresponding P values are provided in Figure 3.

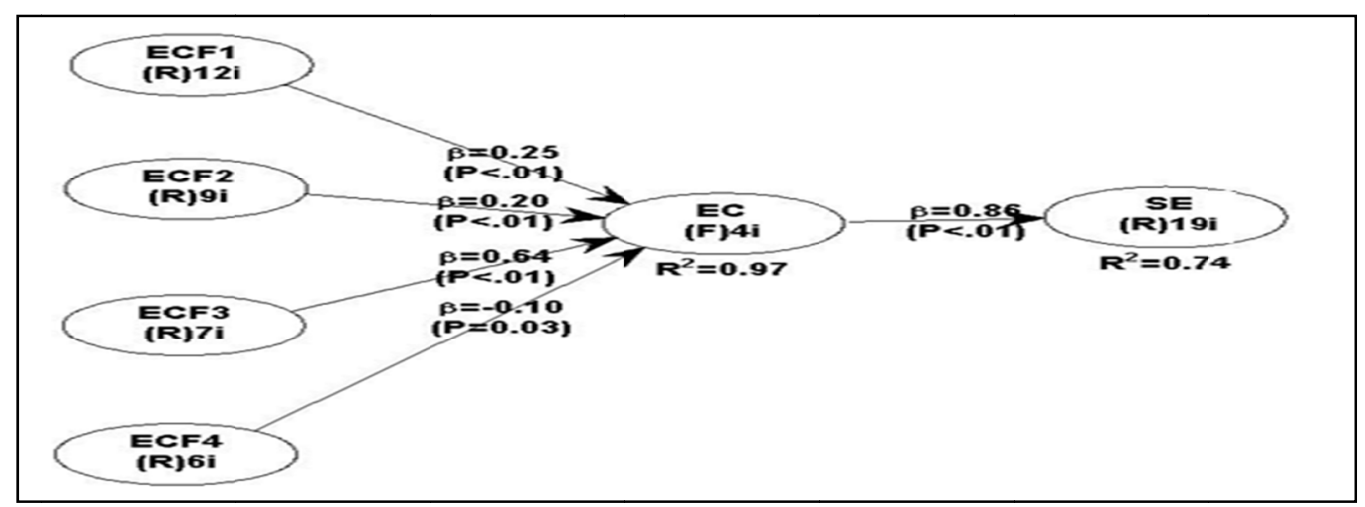

Figure 3. Model Validation - Model Fit Indices and P values

Source: PLS Analysis

\subsubsection{Linkage between Entrepreneurial Competency and Social Entrepreneurship}

Entrepreneurial competency explained 74 percentage of the variation in social entrepreneurship. P value is less than 0.01 , hence, it can be inferred that the linkage between Entrepreneurial competency and social entrepreneurship is statistically significant.

Entrepreneurial competency has a positive relationship $(\beta=0.86)$ with social entrepreneurship, which indicates 
that as the entrepreneurial competency increases, social entrepreneurship also increases. It also indicates that one unit change in the entrepreneurial competency would change social entrepreneurship by 0.86 units.

\section{Discussion}

It is evident from the study that entrepreneurial competency has got a statistically significant direct positive relationship with social entrepreneurship. Entrepreneurial competency accounts for about 74 per cent variation in social entrepreneurship.

The results of the study brought about the significance of entrepreneurial competency in inculcating social entrepreneurship among micro entrepreneurs. Social entrepreneurship, being a concept of social relevance, essentially can fulfill the much debated social responsibility of entrepreneurs. While designing various training and development programs for micro entrepreneurs, policy makers should focus on various entrepreneurial competency factors, which can potentially contribute to the characteristic of social entrepreneurship among them.

The study evaluated the levels of entrepreneurial competency and social entrepreneurship among micro entrepreneurs in Kerala. An effort was also made to identify the extent to which entrepreneurial competency contributes to social entrepreneurship. The study also attempted to build a model that explains the linkage between entrepreneurial competency and social entrepreneurship.

The results of the overall analysis led to the revelation about the catalytic role played by entrepreneurial competency in developing social entrepreneurship among micro entrepreneurs in Kerala.

\section{Managerial Implications}

The findings of the current study indicate that competency matters in describing social entrepreneurship. The study results may help the academia, trainers and researchers to identify new ways of competency development. It will also help them to focus on innovative training programs, that focuses on development of entrepreneurial competencies and to come out with tailor-made solutions to the problems of micro enterprises. It is also important to have an understanding of social entrepreneurship that ultimately contributes to social performance of the business, which in turn will definitely provide a competitive edge to micro enterprises.

\section{Directions for Future Research}

This section is intended to highlight the importance of future research to cross-validate the results of the present study as well as to determine the generalizability of these results. Specifically, future research should collect data on all variables from other States to verify and validate the results, test model applicability in other States and in other countries, examine the model generalizability in other contexts.

Future research would also benefit from a longitudinal approach to data collection. This would enable the researchers to explain how the relationship between entrepreneurial competency and social entrepreneurship change over time.

Another interesting opportunity would be to undertake a comparative study among men and women micro entrepreneurs, to ascertain whether there is any gender difference in the relationship between entrepreneurial competency and social entrepreneurship.

Studies can also be undertaken to assess the social performance of micro enterprises run by members of self-help groups.

\section{References}

Abu-Saifan, S. (2012). Social entrepreneurship: Definition and boundaries. Technology Innovation Management Review, February, 22-27.

Adam, E. \& Chell, E. (1993). The successful international entrepreneur: A profile. Paper presented at the Twenty third European Small Business Seminar. Belfast: Northern Ireland.

Alveraz, S. A., \& Barney, J. B. (2007). Discovery and creation: Alternative theories of entrepreneurial action. Strategic Entrepreneurship Journal, 1, 11-26. https://doi.org/10.1002/sej.4

Bacq, S. \& Janssen, F. (2011). The multiple faces of social entrepreneurship: A review of definitional issues based on geographical thematic criteria. Entrepreneurship and Regional development, 23(5-6), 373-403.

Bartlett, C. A. \& Ghoshal, S. (1998). Managing across borders: The transnational solution (2nd ed.), Boston: Harvard Business School Press.

Bird, B. (1995). Toward a theory of entrepreneurial competency. In J. A. Katz \& R. H. Brockhaus, Sr (Eds.), 
Advances in entrepreneurship, firm emergence and growth (pp. 51-72). Greenwich, Conn: JAI Press

Boyatzis, R. E. (1982). The competent manager: A model for effective performance. London: Wiley.

Brophy, M., \& Kiely, T. (2002). Competencies: A new sector. Journal of Industrial Training, 26(2/3/4), 165-176.

Brouard, F. \& Larivet, S., (2010). Essay of clarifications and definitions of the related concepts of social enterprise, social entrepreneur and social entrepreneurship. In Fayolle A., \& Matlay H. (Eds.), Handbook of research on social entrepreneurship, Chetelham: Edward Elgar.

Canadian Centre for Social Entrepreneurship. (2001). Social Entrepreneurship. Discussion paper No.1. https://doi.org/10.1.1.194.4683\&rep=rep1\&type=pdf

Cannon, C. (2000). Charity for Profit: How the new social entrepreneurs are creating good by sharing wealth. National Journal, 16, 1898-1904.

Fornell, C., \& Larcker, D. F. (1981). Evaluating structural equation models with unobservable variables and measurement error. Journal of Marketing Research, 18(1), 39-50.

Garavan, T. \& McGuire, D. (2001). Competencies and workplace learning: Some reflections on the rhetoric and the reality. Journal of Workplace Learning, 13(4), 144 - 164.

Gibb, A. A. (2005). The entrepreneur as the core competence of the firm: Implications for management educators. Entrepreneurship, Innovation and Small Business Network, (2) 2.

Hair, J. F. Jr., Black, W. C., Babin, B. J., \& Anderson, R. E. (2009). Multivariate data analysis, (7th ed.) Upper Saddle River, NJ: Prentice Hall.

Kerlin, J. (2006). Social enterprise in the United States and Europe: Understanding and learning from the differences. Voluntas, 17, 247-263.

Lau, T., Chan, K. F. \& Man, T. Y. Y. (2000). The entrepreneurial and managerial competencies of small business owner/managers in Hong Kong: Conceptual and methodological considerations. In Sancehez, R. \&Heene, A. (Eds.), Research in competence-based management: Advances in applied business strategy, Connecticut: JAI Press. 187-216.

Mair, J., \& Nobao, E. (2003). Social entrepreneurship: How intentions to create a social enterprise get forward. Working Paper 521, IESE Business school University of Navarra. Retrieved from http://www. ssireview.org/articles/entry/social_entrepreneurship

McClelland, D. C. (1973). Testing for competence rather than for intelligence. American Psychologist, 28, 1-14.

McGregor, J., \& Tweed, D. (2002). Profiling a new generation of female small business owners in New Zealand: Networking, mentoring and growth, Gender, Work and Organization, 9(4), 420-438.

Miller, T. L., Wesley II, C. L. \& Williams, D. E. (2012). Educating the minds of caring hearts: comparing the views of practitioners and educators on the importance of social entrepreneurship competencies. Academy of Management Learning and Education, 11(3), 349-370.

Mitchelmore, S., \& Rowley, J. (2010). Entrepreneurial competencies: a literature review and development agenda. International Journal of Entrepreneurial Behavior and Research, 16(2), 92-111. http://dx.doi.org/10.1108/13552551011026995

Muzychenko, O. \& J., Saee (2004). Cross cultural professional competence in higher education. Journal of Management Systems, 16(4), 1-19.

Nunnally, J. C., \& Bernstein, I. H. (1994). Psychometric theory (3rd ed.). New York: McGraw-Hill.

Nyssens, M. (2006). Social enterprise at the crossroads of market, public policies and civil society. London: Routledge.

Prahalad, C. K. (2006). The innovation sandbox. Strategy+Business, Autumn, 44, 62-71. Retrieved from www.strategy-business.com/press/freearticle/06306

Ramasamy, H. (1995). Productivity in the age of competitiveness: Focus on manufacturing in Singapore. APO Monograph Series, 16, Asian Productivity Organization.

Spencer, L. M., \& Spencer, S.M. (1993). Competence at work. Human resource quarterly, New York: Wiley, 372.

Stuart, R. \& Lindsay, P. (1997). Beyond the frame of management competencies: Towards a contextually embedded framework of managerial competence in organizations. Journal of European Industrial Training. 


$$
\text { 21(1), 26-33. }
$$

Thompson, J., Alvy, G. \& Lees, A. (2002). Social entrepreneurship: A new look at the people and the potential. Management Design, 38(5), 328 - 338.

UNIDO (2002). Strengthening organizational core values and managerial capabilities. Human Resource Management Branch, UNIDO. Retrieved from: http://www.unido.org/fileadmin/media/documents/pdf/Employment/UNIDOCompetencyModel-Part1.pdf

Veronika, B., Baiba, R., \& Inga, R. (2015). The Social Entrepreneur as a promoter of social advancement. Procedia - Social and Behavioral Sciences, 185, 469-478.

Wiklund, J. (1999). The sustainability of the entrepreneurial orientation: Performance relationship. Entrepreneurship Theory and Practice (Fall), 37-48.

Zahra, S. A., Rawhouser, H. N., Bhawe, N., Neubaum, D. O., \&Hayton, J. C. (2008). Globalisation of social entrepreneurship opportunities. Strategic Entrepreneurship Journal, 2(2), 117-131.

Zampetakis, L. A. (2008). The role of creativity and pro-activity on perceived entrepreneurial desirability. Thinking Skills and Creativity, 3(2), 154-162.

\section{Copyrights}

Copyright for this article is retained by the author(s), with first publication rights granted to the journal.

This is an open-access article distributed under the terms and conditions of the Creative Commons Attribution license (http://creativecommons.org/licenses/by/4.0/). 